\title{
The effect of hypoxic training using an altitude mask for $3000 \mathrm{~m}$ runners
}

\author{
"Dr/ Abeer Mohamed Sayed Abd el Salam
}

*** Dr/ Fatma Sayed Abd el Alim Muhamed Ajlan

Abstract

Hypoxic exercises have an effective impact in achieving achievement in the long-distance race, so the researchers were interested in knowing the impact of hipoxic training using a highland mask on the players of the $3000 \mathrm{~m}$ running race. The researchers used the experimental method by designing two groups, one controlled and the other experimental in a measurement (tribal and remote) manner.

The search sample was selected in the intentional manner of the players (3000) $\mathrm{m}$ from the Cairo Athletics Area under (20) years and was composed of (21) players. The program was applied for 60 days by (3) units per week with a total of (24) unit time units (90) S.

Some of the results were as follows:

There are statistically significant differences between the two dimensions of the control and experimental groups in the physical and physiological indicators of the body and the digital level of the players of $3000 \mathrm{~m}$ running

The researchers also recommended several recommendations, including:

The application of the proposed training program, attention to training in which the highland mask is used because of its positive impact in the development of physiological devices and the physical ability of players.

Keywords: hypoxic, Elevation Training Mask,

\section{Introduction and search problem:}

The current levels and figures recorded by the world champions have become amazing, after this qualitative progress in the sciences associated with applications in the field of sports, particularly sports training science and sports physiology, and hypoxic exercises have an effective impact in achieving achievement in the (3000) meter/running race if used correctly.u

Larry Kenney et all believes that by taking advantage of the various studies and theories of the principles and foundations of physiology and sports training, the study of the functional status of the respiratory and periodic systems is of the utmost importance for assessing and trackingthe training situation oflongdistance racers (endurance) in general

* Assistant professor at sport recreation dep., faculty of physical education, Mansoura university of Egypt Lecturer in the Department of field and track competitions training, Faculty of Physical Education for Girls. Helwan University.

** Assistant professor at sport recreation dep., faculty of physical education, Mansoura university of Egypt Lecturer in the Department of field and track competitions training, Faculty of Physical Education for Girls. Helwan University..

Assiut Journal For Sport Science Arts 
and racing (3000 meters) Special running, which requires a long physical effort in addition to its influential role in the level of racers where these two devices work to provide the necessary oxygen in the various vital processes of the working muscles and the heart muscle and complete metabolism and supplement the nutrients needed to rebuild the energy compounds of the body where the breaths follow between inhaling and exhalation to provide oxygen used in many metabolisms (30:164)

Mohammed Shehata (2005) explains that the development of both the TSA and the periodic system depends on training used to develop theendurance element, which also indicates the importance of directing the training process to the development of the work of the lungs and heart and increased sizes and pulmonary capacities. $(18: 16)$

Emad Badrawi (2016) points out that the $3000 \mathrm{~m} /$ running requires a certain amount of special endurancesuch as periodic respiratory endurance, strength tolerance and speed tolerance, which affects the level of long-distance racers, and special endurance is always time-bound and varies from effectiveness to efficiency. (16:3)

Abdul Moneim Badir et al. (2012) adds that special endurance means the ability of the rider to cope with fatigue to achieve the highest level of functional efficiency of different devices according to the nature and characteristics of each sports activity and since the special endurance varies according to the nature of this activity. (15: 100)

Bastwissi Ahmed (2014 AD) believes that the special endurance is of medium time and whose performance does not exceed (8-30) minutes, in which the level of endurance affects the improvement of the body's ability to consume oxygen as well as the level of endurance affects the efficiency of the heart where the pulse rate in comfort decreases and the pulse rate increases immediately after exertion as a result of increased blood paid in each pulse. $(2: 183,184)$

Both "Raisan Khuraibet" and "Abu Al-Ela Abdel Fattah" (2016 AD) indicate that training at heights now has training tools used to simulate many changes in the body by changing the partial pressure of oxygen using an altitude mask and modified training tents. $(8: 673,674)$

Porcari JP, Probst(2016) adds that the Highland Mask is a modern sports tool used as a tool that simulates training on the highlands, consisting of different design valves that control the entry and exit of air from the nose and mouth at different heights starting from (3000) feet (918 meters) and $(6,000)$ feet (18) feet28 meters) and height(9000) feet(2743 meters)and $(12,000)$ feet $(3658$ meters) to $(18,000)$ feet (5486 meters) above sea level (29:87), figure no. (1), (2) and (3) shows the shape of the mask and the way it is worn. 


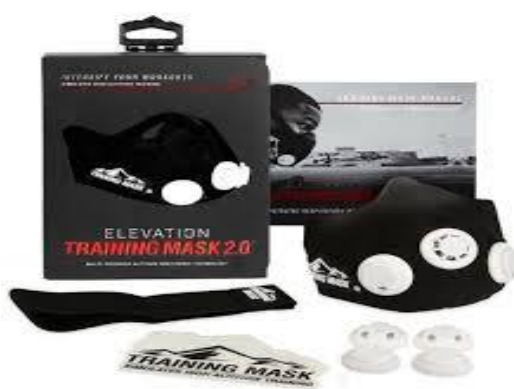

Shape Number 1

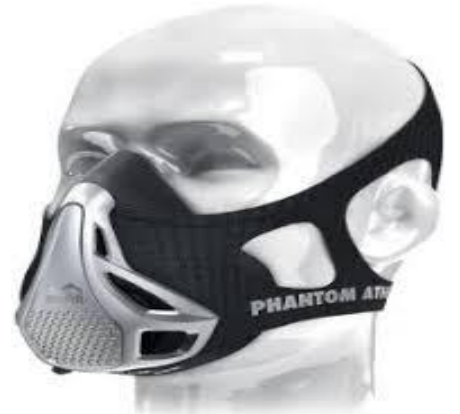

Shape Number (2)
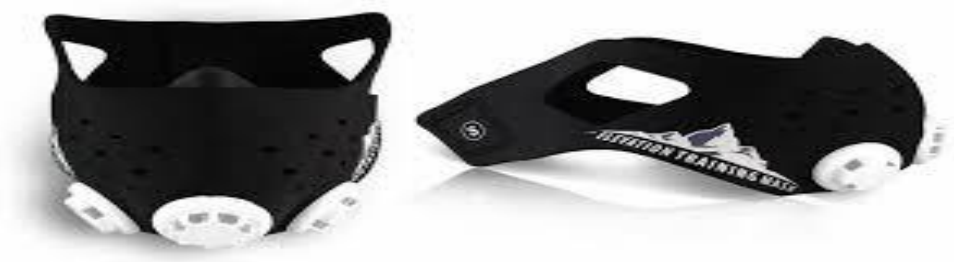

Shape Number(3)

This is confirmed by" Saadeddine Chernoubi", "Abdul Moneim Ibrahim (2001) that the hipoxic exercises have contributed strongly and clearly to the digital achievement of enemy competitions. $(10: 27)$

According to"Dagnosh Aqaba" (2018) that the subject of training in the Highlands is one of the topics still under study and follow-up by specialists in this field in order to develop and deliver players to the highest levels before the competition, but the coach must follow every small and large in order to make the training process successful and not to fail talented players in particular, who have a genetic ability that needs to develop and refine talent in order tosucceed. $(5: 82)$

"Mufti Ibrahim" (2001) points out that sports training is a physical and educational process aimed at achieving high results it is necessary to take care of the process of selecting training loads in order to make the requiredadjustment process either physically or physiologically in order to avoid reaching the stage of stress or fatigue, and since one of the most important objectives of training is to improve Players' abilities are as physical as possible, so when trying to develop the level of players, sports workers need the necessaryknowledge of the information associated with themethods and means of training because of their impact on the development of physical qualities in general and special physical and physiological requirements in addition to its positive impact At the level of the player skill.(19:31)

Sports training is an organized educational process that is scientificand practical, relying on scientific laws aimed at fully preparing the athlete from all sides to the world 
level through the use of legalized physical pregnancy, which is commensurate with the individual abilities of athletes.

Sports training is "a complex practical plan aimed mainly at elevating or decreasing the level of sport and landing it (in case of retirement) and biologically medically is a group of targeted kinetic triggers that go beyond our intensity and aim to createorganic and functional changes to adapt to thenew situation." (9:330) Mohammed Osman (2008) also explains that "sports training is a wellthought-out planned process carried out through repetitive muscular action) physical pregnancy (aimed at improving the physical, tactical and technical level, psychological and mental ina neighborhood where the severity of the pregnancy usedexceeds a limit with us that varies from individual to individual." (20:205)

Sports training is a stand-alone science based on many other sciences, whether scientific or human, such as anatomy, sports physiology, biomechanics and psychology, all of which are sciences associated withsports trainingscience.

According to Aladdin Mohamed Aliwa (2006), training science and sports physiology are important sciences, and scientists have been interested in physical effort since the past centuries when they studied how the body functions when performing physical exertion and observing, recording and studying changes, especially the positive effects of daily exercise. (17: 155)

According to Safaa Abdul Wahab and others (2014), the goal of sports training specialists is to race between scientific and technological development and the innovation of methods and training methods used to improve the achievement and improve it for the better by using all the sciences to provoke the components of the athlete and exploit his potential with the least possible energy to delay the appearance of fatigue and finish the game with minimal effort, so the training is used in order to continue the motor performance as much as possible throughout the period without changing, whether in training or match, including this training. The development of special endurance (speed, strength) is resistance training of all kinds as well as training heights and slopes benefiting from body weight as ascent is the basis for the development of strength tolerance and descent based on the development of speed tolerance, and despite scientific development in the field of sports training, further research and studies to reach many scientific facts may contribute to the detection of the best methods and methods developed that contribute to the development of all sports events optimally in an attempt to drawthe fruits of the energy of the humanbody To the fullest extent(12:2) Bahaa Salameh (2000) and Nasser Al-Suwayfi(2010) agree that the study of sports physiology is useful in describing and interpreting physiological responses and adaptations that have helped develop the methods of education and training for sports activities, and that notregular training brings about functional change. In the efficiency of the body organs, where physical exercise plays

Assiut Journal For Sport Science Arts 
its role in preparing games and sports competitions, it is an essential part of the numbers of sports in general numbers and especially for all sports events if committed to practicing them in an orderly manner according to scientific foundations specifically designed to suit the type of work practiced by the trainee. $(3: 25(22: 259)$ According toAroussen (2006), the study in the highlands under lack of oxygen is useful (especially longdistance runner), this type of study and adaptation improves, stimulates and brings beneficial changes at the level of muscle cells that have the ability to use energy and withstand effort and this adaptation improves red blood cells, which in turn improve the ability of the athlete's air performance. $(25: 71)$

$$
\text { Robach's study (2006), }
$$

conducted on 11 runners in middistance races through results after the end of the18-day training period, proved that the principle of "living in the highlands and training at sea level" is the best way to raise and improve air performance (by increasing the proportion of red blood balls and increasing the maximum speed ofoxygen consumption when landing at sea level). (32:81)

Bertin, Michau (2011) also believes that life and training in the highlands under hypoxia conditions creates many adaptations several weeks after returning to sea level, especially the concentration ofblood cells andincreased blood cell production, which helps to Increasing the amount of oxygen it transmits to muscles, and also reduces heart pulse and lack of heart impulses compared to what it was before when landing at sea level, thus making these adjustments the most important with continuity and improving the level of air performance when returning to sea level and figure 4 shows blood components.) $26: 183$ )

"Hara Diterson" (2010) defines the exercise as"every structured learning whose goal is to advance rapidly both physically and mentally and to increasethe learning ofman's tactical mobility."

Highland training is one of the methods of exercise adopted in recent years because of a scientific process that has a positive impact on many sports activities due to the change in gravity and weight of the body and which has caused physiological and chemical changes as a result of these effects. (132: 7)

Amer Ibrahim Fakher (2013)points out that "running on the heights for the athlete is a general tolerance and is a special method of developing the physical capacity of the athlete as it depends on the change of speeds depending on the nature of the earth and makes aspeed and increase the effort when climbing to High where muscles work against gravity and when the athlete falls from high speed increases and effort decreases and the muscles work with gravity as this type of training is a strong exercise as a result of difficulty performing so it is a free exercise that does not adhere to a special and specific training program, It is recommended that the ground be earthy or grassy and unhindered when training so that no injury occurs to players such as tension and muscle tears, and the coach can 
determine the distance and intensity of the training and according to the physical goal he seeks (13:140)

Abdul Rahman Abdul Hamid Zaher (2000) points out that scientific studies have shown that the formation of a training pregnancy without studying its physiological effects on the body often leads to injuries that appear during the training season and that the mere identification of the mechanics of the body's physiological responses helps to improve the body's responses and control them in order to effectively improve them (14:12)

Training in the highlands depends mainly on the knowledge of the physical and climatic variables that distinguish high areas from the sea surface and their impact on the physiological functions of the body's organs.

Shining Ismail Nasser (2005) indicates that gravity decreases from the equator to the poles by up to 53 percent. For these reasons, the process of holding tournaments and competitions in high places in some sports of all kinds is one ofthe reasons for the improvement in the numbers of these competitions as a result of dealing with physicalvariables found in the highlands. $(11: 124)$

According to Bahauddin Salameh (2000 AD), the effects of gravity lie in influencing the weight of the body as well as reduced pressure within the capillaries at the heart level, high pressure inside the capillaries below the heart level, and the temperature drops about one degree Celsius as we rise. About $150 \mathrm{~m}$ below sea level, and the decrease in temperatures in this way may lead to a lot of health risks per capita, where humidity decreases, dehydration increases and the body loses a lot of water during breathing and also lowerbreathing rate $(3: 258)$

Khaled Haddadi (2014) also explains that many studies have dealt with the topic of education in the highlands, and discuss the impact of physiological adjustments resulting on different organs of the body, both physiologically and functionally and their important and positive role in raising the level of aerobic performance, especially in The competitions are half long and long, as shown by the digital level and the outstanding achievements of Theopian and Kenyan athletes in the competitions, and we cannot explain their high level from countries more advanced and technologicalin terms of father hath and devices other than their superiority in the environment in which they live and train and distinguished by lack of oxygen. $(4: 5)$ As a result of the great disparity between the world and regional digital levels from the Egyptian national levels in the World Athletics Championships, which were held as described in schedule No. 1 also the Olympic Athletics Championships, the researchers conducted research as a way to raise the level of athletes (3000) meters/running. 
Table (1)

\begin{tabular}{|c|c|c|c|c|c|c|c|}
\hline الرياضنينين & المنافسات & 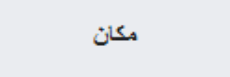 & تازيخ & البلث & المديثة & السنة & الثوزة \\
\hline 1,355 & 41 & ملعب هلسنكي الأولمبي & 7 أغسطس - 14 أغشطس & 1 & هلنسنكي & 1983 (نفاصبل) & 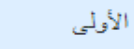 \\
\hline 1,451 & 43 & ملعب الأولميبكى & 28 أغسطس - 6 سينَمبز & I 10 & ل دوما & 1987 (نفاصبل) & التالتبة \\
\hline 1,517 & 43 & الملعب الأولمبي الوطنى & 23 أغسطس - 1 صينمبز & 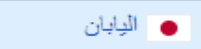 & توكيو & 1991 (نفاصبل) & الذلآة \\
\hline 1,689 & 44 & مرعبدم بنز أرينا & 13 أغسطسن - 22 أغسطس & كس ألمانبا & تَنَونَغَارت & 1993 (نفاصبل) & 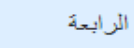 \\
\hline 1,804 & 44 & ملعب ألعاب القتىى & 5 أغسطس - 13 أغسطس & ل & غونتبزغ & 1995 (نقاصبثل) & الخامسة \\
\hline 1,882 & 44 & ملعب أكبينا الأولمبي & 1 أغسطس - 10 أغسطس & 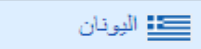 & آنتينا & 1997 (نفاحبث) & المبادسة \\
\hline 1,821 & 46 & ملعب الكارئوخا & 20 أغسطسن - 29 أغشطس & ك & إتيبيلية & 1999 (نفاصبي) & اللمابعة \\
\hline 1,677 & 46 & ملعب الككومنولت & 3 أغشطس - 12 أغشطس & 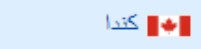 & إدمنثنىن & 2001 (نفاصبل) & التامنة \\
\hline 1,679 & 46 & ملعب فرنهـا & 23 أغسطسن - 31 أغسطس & | & سان دونى & 2003 (نقاصبثل) & الثدانسية \\
\hline 1,688 & 47 & ملعب هلنسنكي الأولمبي & 6 أغشطن - 14 أغشطن & 1 & هلنسiكي & 2005 (نفاصبل) & العاتَزة \\
\hline 1,800 & 47 & ملعب ناغاي & 24 أغسطسن - 2 مينَمبز & • • ل & | أومـاكا & 2007 (نفاصبيل) & الدادية عتر \\
\hline 1,895 & 47 & الملعب الأولمبي & 15 أغسطسن - 23 أغسطس & كس ألدانبا & برئين & 2009 (نفاصبث) & الألتانية عتر \\
\hline \multirow[t]{4}{*}{1,867} & 47 & ملعب ديخو & 27 أغضطنس - 4 عنيَمبز & :": كوريا الجنوبية & | ل ديغو & 2011 (نفاصبل) & التلالة عضر \\
\hline & & ملعب لوزنيكي & 10 أغسطسن - 18 أغسطس & لم دوميا & موبكى & 2013 (نفاصبل) & الر ابعة عتر \\
\hline & & ملعب بكين الوطتى & & ل & | بيكين & 2015 (نفاصببل) & الذامسدة عتر \\
\hline & & ملعب لثند الأولمبي & & 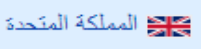 & لندن & 2017 (نفاصبل) & المبادسة عتر \\
\hline
\end{tabular}

Table \#1 Hence the idea of research, which is to use highland training for its ability to develop a balance in the strength of the muscles of running players (3000) meters/run, thus enabling the development of a new method of training that can benefit trainers in the training process.

According to the researchers, the importance of the research lies in the fact that it is an attempt to simulate highland training through the use of the TederYP mask to reduce the proportion of inhaled air and thus reduce the oxygen ratio used in breathing to develop physiological and functional abilities and improve the level of athletic performance, and the researchers suggested the use of the training mask Within the training program in a codified manner, through whatthe researchers saw that from previousstudies, which indicated the importance of using anaerobic modus operandi (lackofoxygen) in improving the physical and physiological qualities of a racing player (3000) meters/running.

Reseach objective: The research aims to identify the impact of hippyxic exercises using a highland mask in:

1. Development of some physical functional indicators such as (men's ability,muscular endurance),

2. Development of some physiological indicators (vital capacity, maximum oxygen consumption VO2max),

3- Improving the digital level of players (running $3000 \mathrm{~m}$ ) in the search sample.

\section{Research hypothes:}

1- There are statistically significant differences between the tribal and

Assiut Journal For Sport Science Arts 
remote measurements of the control group in (capacity for soft tremormuscular endurance - biosurgy maximum oxygen consumption digital running level of $3000 \mathrm{~m}$ ).

2- $\quad$ There are statistically significant differences between the tribal and remote measurements of the experimental group in (man's capacitymuscular endurance- biosurgymaximum oxygen consumption- a digital levelofrunning $3000 \mathrm{~m}$ ).

3- There are statistically significant differences between the two dimension measurements of the "controlled, experimental" groups in (capacity for men - muscular endurance - biosurgy maximum oxygen consumption digital running level of $3000 \mathrm{~m}$ ).

\section{Previous studies:}

1- "Dufour (2005) (28) conducted a study entitled "Access to Optimal Aerobic Performance" (hypoxie intermittente)and the study aimed at identifying the impact of training in the highlands and the researcher used the experimental method using tribal and remote measurement and the researchsample was selected in the intentional manner and number of (18) long-distance runners, and the results concluded that training in the highlands has a positive and effective role in improving aerobic performance.

2- (2013) (6) A study entitled "The impact of the use of highland masks on some aspects of neural processes in the runners of the arena and the field" and the study aimed to know the impact of the use of highland mask at different heights with different difficulties in the flexibility of some
The two researchers used the experimental method, and the research sample was selected in the blind wayof 20 advanced-level players in the $15 \mathrm{~km}$ run, and the results reached a development in some aspects of neurological processes due to the effect of using highland masks.

3- "Shmitt" (2014) conducted a study entitled "Training in the Highlands" andaimed at analyzing theimpact of training methods when staying and training in the highlands when exposed to hypotension, and the researcher used the experimentalmethod by applying a training program for a period of at least (1) 15) On the day the number of samples (20) athletes was selected in the intentional way among the sport of skiing, swimming and enemy and were assignedto(6) skating athletes, (9) swimming athletes and (5) runners in the field of speedand the results indicated that aerobic exercises are the most appropriate, The increase inVO2 MAXshows several physiologicalvariables, the most important of which is an increase in the volume of maximum oxygen and an increase in the concentration of hemoglobin,P.M. A)Increased aerobic speed, (V.M.A) and aerobic capacity.

4- Yasser Abedin Suleiman (2016) (24) conducted a study entitled "The effectiveness of hippyxi training in the development of some special functional capabilities and the level of digital achievement of the contestants (1500) meters conducted", and the study aimed to identify the impact of hipbox training on the functional abilities of Race (1500) running 
meters, digital level of racers (1500) running meters, and the researcher used the experimental method on a sample of (6) players of racers (1500) running meters in the team of the University of Banya Athletics (Middle Distance), Themost important research tools were: functional measurements measurement of the digital level ofracers (1500) meters/running and training program using hipbox training, and the most important results: the effectiveness of the proposed training program using hipbox training in improving functional capabilities) maximum to startas absolute oxygen The relative co2 consumption - maximum heart rate - breathing rate per minute - pulmonary ventilation - biosphere - time of silence (for racers (1500) meters/running and led to an improvement in the digital level of racers (1500) meters/running.

5- Emad Faraj Badrawi (2010) (16) conducted a study entitled "Special Endurance Training Program and its impact on some biochemical and physiological variables and physical effort of players (5000) meters/running in Iraq", and the study aimed to identify the impact of a training program for the race (5000) meters/running on some biochema variables Theresearcher used the experimental method, and the research sample reached(8) players, and the most important conclusions were that there was a positive impact of the proposed training program for the development of speed tolerance and strength tolerance and statistically indicative of biochemical variables (Pyramid OneBeta Androvin - Lactic Acid) in racers (5000) meters/running.
6- "Mohamed Zakaria Isles" (2005) (21) carried out a study entitled "The impact of heboxic training on the efficiency of the respiratory league and the level of performance in the youth of boxing", the study aimed at identifying the impact of hippyxitrainingk on the efficiency of the respiratory league and the level of performance in the young boxing, and the researcher used the experimental method on a sample of 20 boxers One of the most important research tools of the proposed program, which lasted (8) weeks, is the testing of thephysical physiologicalmeasurements, and the most important results are the effectiveness of the proposed training program using hipbox training in the development of the efficiency of the respiratory league and the level of performance of the boxing originater.

\section{7- Daniel Pierce (2013) (27)} carried out a study entitled "The impact of the repetition of precompetition hipbox training at the level of rugby players' performance", where the study aimed to identify the impact of wearing a training mask frequently in training and to know the impact on the level of players during Rugby competitions in England included (42) players trained with mask for (4) weeks by (3) units per week and the most important results were improved metabolism of anaerobic and anaerobic energy, increased breathing depth and increased players' fatigue tolerance.

\section{Search procedures:}

\section{Research approach:}

In order to achieve the objectives and duties of the research, the two researchers used the experimental method by designing a skulland two instruments, one officer

Assiut Journal For Sport Science Arts 
and the other experimental in the method of measurement (tribal and remote) due to its suitability of the nature of the research sample.

Research community:

The research community included players in the $3,000 \mathrm{~m} /$ under20s competition registered in the Cairo Athletics Area of the Egyptian Athletics Federation for the training season(2019-2020).

Research sample:
The search sample was selected in the intentional manner of theplayers (3000) meters/ran from the Cairo Athletics Area under (20) years of age and consisted of (21) players.

It was divided as follows:

- (5) Exploratory sample players.

- (8) Officers group players.

- (8) Experimental group players.

The following table shows the distribution of the research sample and the research community.

Table (2)

Description of the study community and research sample

\begin{tabular}{c|c|c|c}
\hline \hline \multicolumn{2}{c|}{ Statement } & Number & Percentage \\
\hline \hline \multicolumn{2}{c|}{ The totality of society } & 48 & $100.00 \%$ \\
\hline \multirow{4}{*}{ Sample study } & Reconnaissance sample & 5 & $10.42 \%$ \\
\cline { 2 - 4 } & Officer Group & 8 & $16.67 \%$ \\
\cline { 2 - 4 } & Core group & 8 & $16.67 \%$ \\
\cline { 2 - 4 } & Total sample & 21 & $43.75 \%$ \\
\hline \hline
\end{tabular}

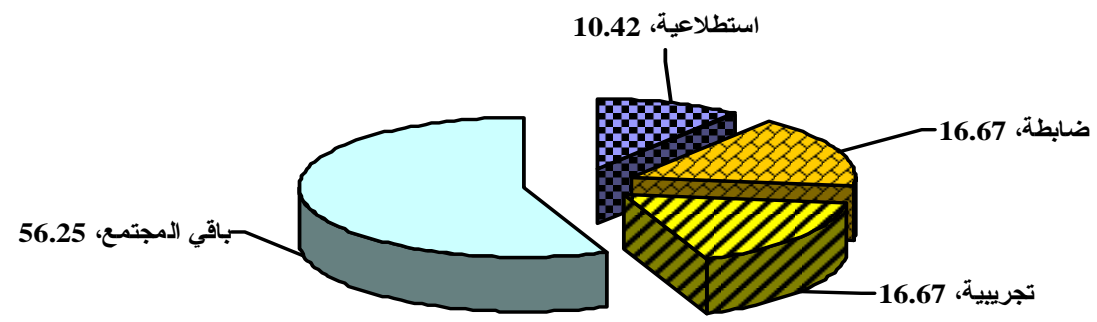

باقي المجتمع ه تجريبية ص ضابطة ه استطلاعية

Shape Number (5)

Explains the characterization of the study community and the research sample

- $\quad$ The researchers used 5 players (Republic Champions) as a special sample to conduct scientific transactions for research tools.

Homogenization of the research sample:

Assiut Journal For Sport Science Arts 
Table (3)

Statistical description of individuals of a sample of variables under investigation $\mathbf{N}=\mathbf{2 1}$

\begin{tabular}{l|c|c|c|c|c}
\hline \hline \multicolumn{1}{c|}{ Variables } & $\begin{array}{c}\text { Unit of } \\
\text { measure } \\
\text { ment }\end{array}$ & $\begin{array}{c}\text { Average } \\
\text { Arithmetic }\end{array}$ & Broker & $\begin{array}{c}\text { Deviation } \\
\text { Normative }\end{array}$ & $\begin{array}{c}\text { coefficient } \\
\text { Convoluti } \\
\text { on }\end{array}$ \\
\hline \hline Age & year & 18.667 & 19.000 & 0.483 & -0.763 \\
\hline Length & poison & 172.524 & 171.000 & 7.561 & 0.122 \\
\hline Weight & $\mathrm{kg}$ & 66.333 & 67.000 & 2.763 & -0.132 \\
\hline Training age & year & 4.524 & 5.000 & 0.512 & -0.103 \\
\hline The broad jump of stability & poison & 221.857 & 224.000 & 8.714 & -0.487 \\
\hline The oblique ness of standing & number & 30.190 & 30.000 & 2.482 & -0.219 \\
\hline Pulmonary capacity & degree & 4.947 & 4.950 & 0.105 & -0.147 \\
\hline $\begin{array}{l}\text { Cooper Test Distance } \\
\text { "Running 12q" }\end{array}$ & meter & 2076.952 & 2073.000 & 13.548 & 0.175 \\
\hline VO2 MAX & Milliliter/ & 35.146 & 35.060 & 0.303 & 0.177 \\
\hline $\begin{array}{l}\text { The digital level of running } \\
3000 \text { m }\end{array}$ & second & 501.944 & 502.130 & 2.362 & -0.447 \\
\hline \hline
\end{tabular}

Parity between experimental and controlled research groups:

The researchers found parity between the two research groups

Table (4)

Indication of the differences between the experimental and controlled research groups $\mathrm{N} 1=\mathrm{N} 2=8$

\begin{tabular}{|c|c|c|c|c|c|}
\hline Variables & Groups & $\begin{array}{c}\text { Average } \\
\text { grades }\end{array}$ & $\begin{array}{l}\text { Total } \\
\text { ranks }\end{array}$ & $\begin{array}{c}\text { Mann-Whitney } \\
\text { U }\end{array}$ & Indication \\
\hline \multirow{2}{*}{ Age } & Experimental & 8.00 & 64.00 & \multirow{2}{*}{28.000} & \multirow{2}{*}{0.602} \\
\hline & The officer. & 9.00 & 72.00 & & \\
\hline \multirow{2}{*}{ Length } & Experimental & 8.31 & 66.50 & \multirow{2}{*}{30.500} & \multirow{2}{*}{0.874} \\
\hline & The officer. & 8.69 & 69.50 & & \\
\hline \multirow{2}{*}{ Weight } & Experimental & 8.88 & 71.00 & \multirow{2}{*}{29.000} & \multirow{2}{*}{0.752} \\
\hline & The officer. & 8.13 & 65.00 & & \\
\hline \multirow{2}{*}{ Training age } & Experimental & 7.50 & 60.00 & \multirow{2}{*}{24.000} & \multirow{2}{*}{0.333} \\
\hline & The officer. & 9.50 & 76.00 & & \\
\hline \multirow{2}{*}{$\begin{array}{l}\text { The broad jump } \\
\text { of stability }\end{array}$} & Experimental & 8.81 & 70.50 & \multirow{2}{*}{29.500} & \multirow{2}{*}{0.793} \\
\hline & The officer. & 8.19 & 65.50 & & \\
\hline \multirow{2}{*}{$\begin{array}{l}\text { The oblique ness } \\
\text { of standing }\end{array}$} & Experimental & 8.94 & 71.50 & \multirow{2}{*}{28.500} & \multirow{2}{*}{0.711} \\
\hline & The officer. & 8.06 & 64.50 & & \\
\hline
\end{tabular}


Follow Table (4)

Indication of the differences between the experimental and controlled research groups $\mathrm{N} 1=\mathrm{N} 2=8$

\begin{tabular}{|c|c|c|c|c|c|}
\hline Variables & Groups & $\begin{array}{c}\text { Average } \\
\text { grades }\end{array}$ & $\begin{array}{l}\text { Total } \\
\text { ranks }\end{array}$ & Mann-Whitney U & Indication \\
\hline \multirow{2}{*}{$\begin{array}{l}\text { Pulmonary } \\
\text { capacity }\end{array}$} & Experimental & 9.25 & 74.00 & \multirow{2}{*}{26.000} & \multirow{2}{*}{0.528} \\
\hline & The officer. & 7.75 & 62.00 & & \\
\hline \multirow{2}{*}{$\begin{array}{l}\text { Cooper Test Distance } \\
\text { "Running 12q" }\end{array}$} & Experimental & 8.94 & 71.50 & \multirow{2}{*}{28.500} & \multirow{2}{*}{0.713} \\
\hline & The officer. & 8.06 & 64.50 & & \\
\hline \multirow{2}{*}{ VO2 MAX } & Experimental & 8.94 & 71.50 & \multirow{2}{*}{28.500} & \multirow{2}{*}{0.713} \\
\hline & The officer. & 8.06 & 64.50 & & \\
\hline \multirow{2}{*}{$\begin{array}{l}\text { The digital level of } \\
\text { running } 3000 \mathrm{~m}\end{array}$} & Experimental & 9.50 & 76.00 & \multirow{2}{*}{24.000} & \multirow{2}{*}{0.401} \\
\hline & The officer. & 7.50 & 60.00 & & \\
\hline
\end{tabular}

* الالالة

Table (4) shows that there are no statistically significant differences between the experimental and controlled research groups in the variables under consideration, indicating the parity of the two groups.

\section{Data collection tools:}

1- A survey of specialized scientific references in accordance with the study (6) (16) (21) (24) (27) (28) (33) with the aim of:

- Determine the appropriate measurement method for search objectives.

- The design and preparation of the heboxic training program using a highland mask for $3000 \mathrm{~m}$ players took place.

\section{2- Interview:}

The researchers conducted an interview with specialist experts facility(1) in the field of training using the highland training mask, field competition professors and the track of faculty members of the Faculties of Sports Education to survey the experts in the tests used to measure research variables attached(2), the content of the proposed pilot program (duration of the program, time allocated to the program as a whole and time alone).Attached. 3

\section{3- Data collection forms:}

- A group registration form for collecting sample dataincludes (name, height, weight, age best time achieved) (Annex 5)

- A confirmation form from the player to approve the regularity of the proposed training program (Annex 6)

- This research was done in accordance with the Helsinki Declaration.

\section{4- Tests used:}

The researchers conducted a surveyof previous and similar studies and researches and numbered(7) and some of the scientific references and their number (24) as well as access to foreign scientific articles and researches (9) and on the Internet (2), in order to reach the appropriate tests to measure research variables.Annex (4)

- Testing the broad jump of stability. 
- Oblique slanting test of standing.

- Pulmonary amplitude test.

- Testing the maximum oxygenconsumption.

- Cooper tested running and walking for $12 q$ to measure and estimate maximum aerobic capacity VO2 MAX $(25: 15,16)$

- Digital level test for running (3000) m.

\section{The foundations of the program mode:}

In the light of the training programsavailable to the two researchers, whether from previous studies or the international information network, and after being guided by instructions to use the training mask and heboxy training caveats, the two researchers took into account the following foundations when developing the training program:

1- Achieving the main goal for which the program was set.

2- Thetime of hippyxi training does not exceed (20) minutes in unity.

3 - The number of training units does not exceed (4) training units per week.

4- Taking into account thegradient with the openings of the training mask from three to two to one.

5 - It is not preferable to continue for long periods of training by partially blocking breathing because it hashighintensity loads where it affects the functional organs of the body.

6. It is preferable not to use a training mask for young people and is used for adults only.
7- Before starting the training units take into account the work of the protocol of using the mask in preparation and breathing training.

Taking into account security and safety factors.

Inthis regard,Bastoissi Ahmed (1999) and Abu Ala Abdel Fattah (2003) point out the need to follow the following conditions when using hippyxi training for the training program:

1. When hyperoxyk training is increased by the training programme, the principle of gradualism must be taken into account slowly.

2- Do not usehypoxic exercises for long periods with the speed of stop when you notice the player feeling difficult to breathe, fatigue or headaches.

3. Hippyxi exercises do not have a negative impact on the technical performance of skills.

4-Take into account the non-use of hippyxi training during the competition period.

5- Consider not using hippyxi exercises with pregnant women. (2: 325) $(1: 137)$

\section{First survey:}

The aim was to survey the opinion of a number of (9) experts, annex 1:

- Tests used to measure search variables.

- The content of the proposed programme (duration of the programme, time allocated to the rehabilitation programme as a whole and time of each unit) is attached(3)

The result of the expert survey was as follows: 
Table (5)

Percentage of expert agreement on tests used to measure research variables $\mathrm{N}=9$

\begin{tabular}{l|c|c}
\hline \hline Candidate test & $\begin{array}{c}\text { Iterat } \\
\text { ion }\end{array}$ & Percentage \\
\hline The broad jump of stability & 7 & $77.78 \%$ \\
\hline The oblique ness of standing & 8 & $88.89 \%$ \\
\hline Pulmonary capacity & 9 & $100.00 \%$ \\
\hline $\begin{array}{l}\text { Calculation of maximum oxygen consumption VO2 } \\
\text { MAX Using Cooper's "Running 12Q" test }\end{array}$ & 9 & $100.00 \%$ \\
\hline The digital level of running 3000 m & 9 & $100.00 \%$ \\
\hline \hline
\end{tabular}

The percentage of expert approval of the tests used to measure research variables was determined by the percentage of the Expert Gentlemen's Agreement (100.00\%)

Table (6)

Percentage of expert agreement on the contents of the proposed training programme $\mathrm{N}=9$

\begin{tabular}{c|c|c|c|c}
\hline \hline \multirow{2}{*}{$\mathbf{M}$} & \multicolumn{2}{|c|}{ The content of the program } & $\begin{array}{c}\text { Repeat } \\
\text { approval }\end{array}$ & Percentage \\
\hline \multirow{2}{*}{1} & \multirow{2}{*}{$\begin{array}{c}\text { Duration of the } \\
\text { program }\end{array}$} & 2 Cities & 1 & $11.11 \%$ \\
\cline { 3 - 5 } & & Two months & 7 & $77.78 \%$ \\
\cline { 3 - 5 } & & A month and a half. & 1 & $11.11 \%$ \\
\hline \multirow{2}{*}{2} & \multirow{2}{*}{$\begin{array}{c}\text { Number of weekly } \\
\text { units }\end{array}$} & 4 units & 0 & $0.00 \%$ \\
\cline { 3 - 5 } & & 3 units & 8 & $88.89 \%$ \\
\hline \multirow{2}{*}{3} & \multirow{3}{*}{\begin{tabular}{c} 
Unity Time \\
\cline { 3 - 5 }
\end{tabular}} & Units & 1 & $11.11 \%$ \\
\cline { 3 - 5 } & & 120 minutes & 0 & $0.00 \%$ \\
\cline { 3 - 5 } & & 90 minutes & 9 & $100.00 \%$ \\
\hline \hline
\end{tabular}

The percentage of expert approval of the contents of the proposed training programme was determined by the percentage of the Expert Gentlemen's Agreement $(0.00 \%-100.00 \%)$ This is through the results of the expert survey form, and the two researchers accepted at least (75\%) As a minimum to determine the contents of the proposed training
This is through the results of the expert survey form, and the two researchers accepted at least $(75 \%)$ A minimum limit for determining the tests used in Q-Qsearch variables. 
difficulties that may face the final application process - excluding some exercises because of the difficulty of performing them - determining the number of exercises and the severity of the appropriate pregnancy).

- Ensure scientific transactions (honesty, stability) of research variable measurement tools.

Scientific transactions of research tools:

Believe the tests:

The sincerity of the tests was calculated by calculating the sincerity of discrimination by applying them to

Table (7)

Test honesty labs under consideration $\mathrm{N} 1=\mathrm{N} 2=5$

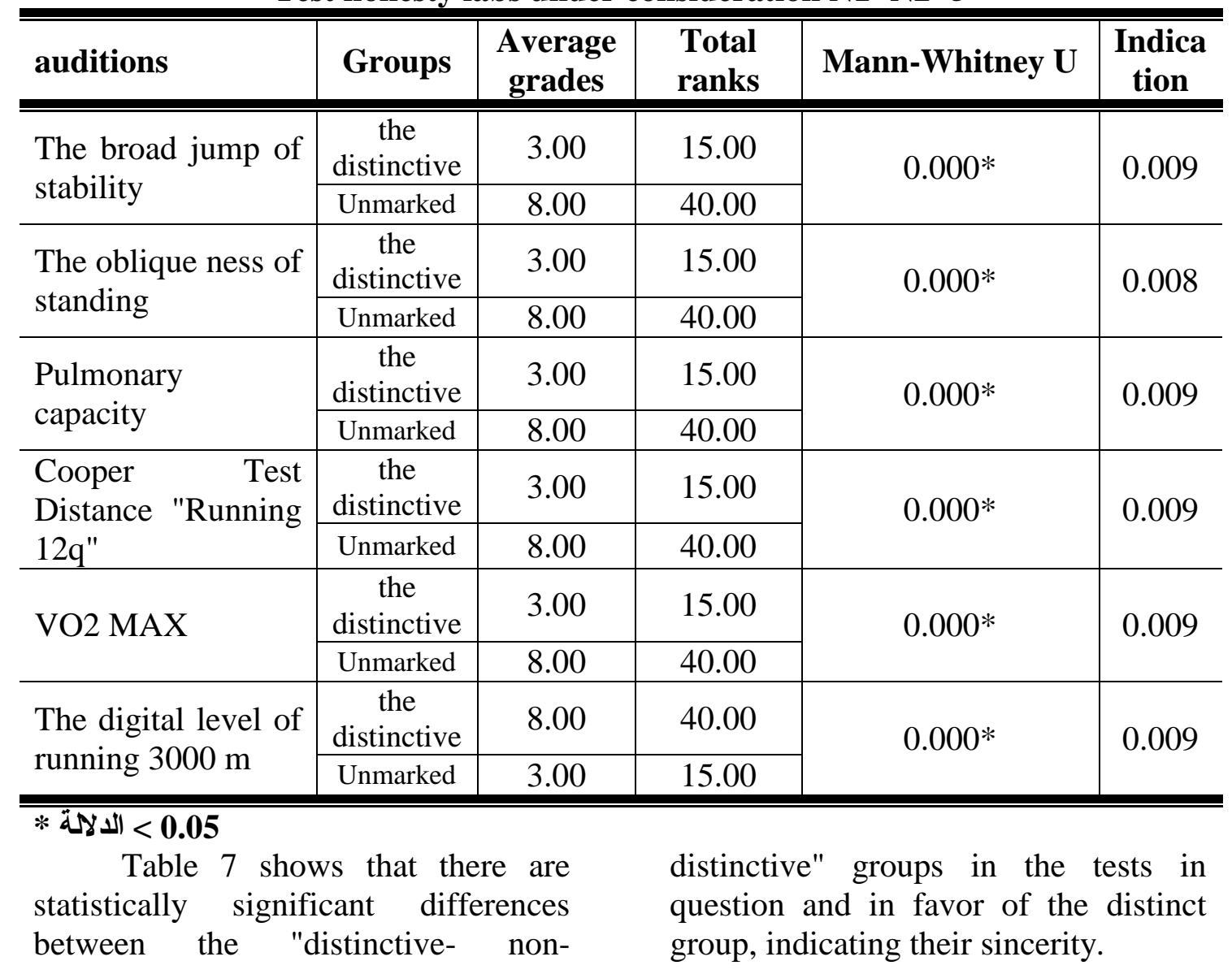

Assiut Journal For Sport Science Arts two groups, representing the initial group "Special Group" (Champions Republic) and its strength players, while the second group (nondistinctive group) represents players Athletics "Reconnaissance Sample" and its strength (5) players from the same research community and outside the basic research sample, on Sunday, September 20,2020, and the following table shows the significance of the differences between the two groups in the tests. (3000) meters/ran in the Cairo area 


\section{Test stability:}

The test stability laboratory was found using the method of applying the test andreteston a sample of 5 players (3000 m) in the Cairo Athletics Area "reconnaissance sample" from the same research community and outside the basic research sample (nondistinctive group), the researchers considered the results Tests for honesty

Table (8)

for (non-featured group) serve as the first application, and then the tests were reapplyed under the same circumstances and with the same instructions after (7) days of the first application on Sunday, September 27, 2020, and the following table shows the correlation transactions between the first and second applications.

Test stability coefficient under consideration $\mathrm{N}=5$

\begin{tabular}{l|c|c|c|c|c|l}
\hline \multirow{2}{*}{ auditions } & \multirow{2}{*}{$\begin{array}{c}\text { unit } \\
\text { scaling }\end{array}$} & \multicolumn{2}{|c|}{$\begin{array}{c}\text { The first } \\
\text { application }\end{array}$} & \multicolumn{2}{|c|}{$\begin{array}{c}\text { Thesecond } \\
\text { application }\end{array}$} & \multirow{2}{*}{\begin{tabular}{l} 
value \\
\cline { 3 - 6 }
\end{tabular}} \\
\cline { 3 - 6 } & $\mathrm{Q} / \mathrm{R}$." \\
\hline \hline $\begin{array}{l}\text { The broad jump of } \\
\text { stability }\end{array}$ & poison & 227.000 & 4.690 & 228.400 & 5.030 & $0.996^{*}$ \\
\hline $\begin{array}{l}\text { The oblique ness of } \\
\text { standing }\end{array}$ & number & 31.600 & 1.673 & 32.400 & 1.673 & $0.964^{*}$ \\
\hline Pulmonary capacity & degree & 4.992 & 0.083 & 5.032 & 0.071 & $0.957^{*}$ \\
\hline $\begin{array}{l}\text { Cooper Test Distance } \\
\text { "Running 12q" }\end{array}$ & meter & 2060.800 & 4.604 & 2064.200 & 5.891 & $0.988^{*}$ \\
\hline VO2 MAX & Milliliter/kg/s & 34.786 & 0.104 & 34.860 & 0.133 & $0.989^{*}$ \\
\hline $\begin{array}{l}\text { The digital level of } \\
\text { running 3000 m }\end{array}$ & second & 501.484 & 2.960 & 501.116 & 2.939 & $0.999^{*}$ \\
\hline \hline
\end{tabular}

* Table "t" value at degree of freedom (3) and indicative level $(0.05)=(0.878)$

Table 8 shows that the value of correlation transactions between the first and second applications of tests has statistically functioning values at a indicative level (0.05), indicating the stability of tests.

Basic study:

\section{1- Tribal measurement:}

The two researchers conducted tribal measurement of the research to measure the variables under consideration on September 27, 2020.

\section{2- Application of theprogram:}

The two researchers applied the training program to the basic research sample from Sunday, 4/10/2020 to Friday 4/12/2020 for a period of (60) days by (3) Units per week with a total
(24) units, each unit had a time of 90 minutes with a total time of $(2,160)$ minutes, of which $20 \%$ of the hipbox exercises had a total time of (432) minutes.

\section{3- Remote measurement:}

The remote measurements of the research variables under study were carried out on the research group according to what was done in tribal measurements on Sunday, 6 December 2020.

\section{Statistical treatments:}

The researchersused the statistical program (SPSS)to process the data statistically and used an account:

- Mean Arithmetic.

Assiut Journal For Sport Science Arts 
- Standard Deviation.

- Test the significance of the differences Man and Whitney MannWhitney (U).

- Coefficient (Person) Simple correlation.

- $\quad$ Improvement rate (\%).

View results:

View and discuss the results of the first imposition:

Table (9)

Indication of the differences between the tribal and remote records of the control group in the variables under consideration $\mathrm{N}=8$

\begin{tabular}{|c|c|c|c|c|c|c|}
\hline & $\begin{array}{l}\text { Type of } \\
\text { signals }\end{array}$ & Number & $\begin{array}{c}\text { Average } \\
\text { grades }\end{array}$ & $\begin{array}{l}\text { Total } \\
\text { ranks }\end{array}$ & قيمة Z & $\begin{array}{c}\text { Level of } \\
\text { significance }\end{array}$ \\
\hline \multirow{3}{*}{$\begin{array}{l}\text { The broad jump } \\
\text { of stability }\end{array}$} & $\begin{array}{c}\text { Negative } \\
\text { grades }\end{array}$ & 0 & 0.00 & 0.00 & \multirow{3}{*}{$2.527 *$} & \multirow{3}{*}{0.012} \\
\hline & $\begin{array}{c}\text { Positive } \\
\text { grades }\end{array}$ & 8 & 4.50 & 36.00 & & \\
\hline & Equally & 0 & & & & \\
\hline \multirow{3}{*}{$\begin{array}{l}\text { The oblique } \\
\text { ness of standing }\end{array}$} & $\begin{array}{l}\text { Negative } \\
\text { grades }\end{array}$ & 0 & 0.00 & 0.00 & \multirow{3}{*}{$2.714 *$} & \multirow{3}{*}{0.007} \\
\hline & $\begin{array}{l}\text { Positive } \\
\text { grades }\end{array}$ & 8 & 4.50 & 36.00 & & \\
\hline & Equally & 0 & & & & \\
\hline \multirow{3}{*}{$\begin{array}{l}\text { Pulmonary } \\
\text { capacity }\end{array}$} & $\begin{array}{l}\text { Negative } \\
\text { grades }\end{array}$ & 0 & 0.00 & 0.00 & \multirow{3}{*}{$2.536^{*}$} & \multirow{3}{*}{0.011} \\
\hline & $\begin{array}{l}\text { Positive } \\
\text { grades }\end{array}$ & 8 & 4.50 & 36.00 & & \\
\hline & Equally & 0 & & & & \\
\hline \multirow{3}{*}{$\begin{array}{l}\text { Cooper } \quad \text { Test } \\
\text { Distance } \\
\text { "Running } 12 q "\end{array}$} & $\begin{array}{c}\text { Negative } \\
\text { grades }\end{array}$ & 0 & 0.00 & 0.00 & \multirow{3}{*}{$2.527 *$} & \multirow{3}{*}{0.012} \\
\hline & $\begin{array}{l}\text { Positive } \\
\text { grades }\end{array}$ & 8 & 4.50 & 36.00 & & \\
\hline & Equally & 0 & & & & \\
\hline \multirow{3}{*}{ VO2 MAX } & $\begin{array}{l}\text { Negative } \\
\text { grades }\end{array}$ & 0 & 0.00 & 0.00 & \multirow{3}{*}{$2.521 *$} & \multirow{3}{*}{0.012} \\
\hline & $\begin{array}{l}\text { Positive } \\
\text { grades }\end{array}$ & 8 & 4.50 & 36.00 & & \\
\hline & Equally & 0 & & & & \\
\hline \multirow{3}{*}{$\begin{array}{l}\text { The digital level } \\
\text { of running } 3000 \\
m\end{array}$} & $\begin{array}{l}\text { Negative } \\
\text { grades }\end{array}$ & 0 & 0.00 & 0.00 & \multirow{3}{*}{$2.521 *$} & \multirow{3}{*}{0.012} \\
\hline & $\begin{array}{c}\text { Positive } \\
\text { grades }\end{array}$ & 8 & 4.50 & 36.00 & & \\
\hline & Equally & 0 & & & & \\
\hline \multicolumn{7}{|l|}{ م > الدلالة 0.05} \\
\hline \multicolumn{3}{|c|}{ Assiut Journal For Sport Science Arts } & & & & \\
\hline
\end{tabular}

View the results of the first imposition:

It states: "There are statistically significant differences between the tribal and remote measurements of the controlling group in (capacity for men - muscular endurance - vital capacity maximum oxygen consumption - the digital level of running $3000 \mathrm{~m}) . "$ 
Table (9) shows statistically significant differences between the tribal and remote records of the controlled group in the variables in question and in favor of remote measurement.

Table (10)

Rate of improvement between the tribal and remote records of the control group in the variables under consideration $\mathrm{N}=8$

\begin{tabular}{l|c|c|c|c}
\hline \multicolumn{1}{c|}{ Variables } & $\begin{array}{c}\text { unit } \\
\text { scaling }\end{array}$ & $\begin{array}{c}\text { Average } \\
\text { tribal } \\
\text { measurement }\end{array}$ & $\begin{array}{c}\text { Average } \\
\text { distance } \\
\text { measurement }\end{array}$ & $\begin{array}{c}\text { Rate of } \\
\text { improvement } \\
\text { \% }\end{array}$ \\
\hline \hline The broad jump of stability & poison & 219.875 & 240.125 & 9.210 \\
\hline The oblique ness of standing & number & 29.500 & 32.625 & 10.593 \\
\hline Pulmonary capacity & degree & 4.918 & 5.168 & 5.084 \\
\hline $\begin{array}{l}\text { Cooper Test Distance } \\
\text { "Running 12q" }\end{array}$ & meter & 2081.375 & 2185.250 & 4.991 \\
\hline VO2 MAX & Milliliter/kg/s & 35.245 & 37.566 & 6.586 \\
\hline $\begin{array}{l}\text { The digital level of running } \\
3000 \mathrm{~m}\end{array}$ & second & 501.518 & 471.456 & 5.994 \\
\hline \hline
\end{tabular}

The rate of improvement between the tribal and remote records of the controlled group in the variables in question and in favor of remote measurement is shown in table 10 , with the improvement rate ranging from $(4.991 \%$ to $10,593 \%)$.

Shape Number (7)

The rate of improvement between the tribal and remote standards of the control group

Discuss the results of the first imposition:

Abu Ala Ahmed Abdel Fattah (2003) (1) and Shining Ismail Nasser (2005) (11) agree that codified training programs always have a positive impact on trainees.

Rafi Saleh, Abdul Razeq alMajdi (2013) (6) also agrees that the differences between tribal and remote measurements in the control group as a result of the application of the exercises used in the training program

\section{Shape Number (6)}

The level of significance of the differences between the tribal and remote records of the control group in the traditional way have a positive result on the improved condition of athletes in the control group.

This is what Osama Ahmed Hassan, Shorouk Mahdi Kazem (2004) (5) points out that training programs have always had a positive impact on the development of athletes' physical and physiological abilities.

This is consistent with the findings of the researchers and the previous presentation in my schedule $(9,10)$ which indicates statistically significant differences between the tribal and remote records of the control group in the variables in question and in favor of remote measurement as a result of the application of the program to them despite not using the highland training mask during the program, which indicates a positive impact of exercise exercise on the physical elements under consideration as we note a change in the rate of 
improvement by up to $9.21 \%$ In the broad jump test of stability and an improvement of $10.59 \%$ in the oblique desperation test of standing, a $5.08 \%$ improvement inpulmonary capacity measurement and a $4.99 \%$ improvement in cooper's test, we also note an improvement of $6.58 \%$ in the VO2MAX test as well as progress in the digital level of the (3000) $\mathrm{m} / \mathrm{run}$ race has reached $5.99 \%$.

Thus, the first imposition, which states:

"There are statistically significant differences between the two measurements of the dome of me and the dimension of thecontrol group in (man's ability - muscular endurance biosurgy - maximum oxygen consumption - digital level of running $3000 \mathrm{~m}) "$

View and discuss the results of the second imposition:

View the results of the second imposition:

It states: "There are statistically significant differences between the tribal and remote measurements of the experimental group in (capacity for men - muscular endurance - biosurgy maximum oxygen consumption digital level of running $3000 \mathrm{~m}$ )."

\section{Table (11)}

Indication of the differences between the tribal and remote records of the experimental group in the variables under consideration $\mathrm{N}=8$

\begin{tabular}{|c|c|c|c|c|c|c|}
\hline & $\begin{array}{l}\text { Type of } \\
\text { signalT }\end{array}$ & $\mathbf{N}$ & $\begin{array}{c}\text { Average } \\
\text { grades }\end{array}$ & $\begin{array}{l}\text { Total } \\
\text { ranks }\end{array}$ & Z قيمة Z & $\begin{array}{c}\text { Level of } \\
\text { significance }\end{array}$ \\
\hline \multirow{3}{*}{$\begin{array}{l}\text { The broad jump } \\
\text { of stability }\end{array}$} & Negative grades & 0 & 0.00 & 0.00 & \multirow{3}{*}{$2.524 *$} & \multirow{3}{*}{0.012} \\
\hline & Positive grades & 8 & 4.50 & 36.00 & & \\
\hline & Equally & 0 & & & & \\
\hline \multirow{3}{*}{$\begin{array}{l}\text { The oblique ness } \\
\text { of standing }\end{array}$} & Negative grades & 0 & 0.00 & 0.00 & \multirow{3}{*}{$2.565^{*}$} & \multirow{3}{*}{0.010} \\
\hline & Positive grades & 8 & 4.50 & 36.00 & & \\
\hline & Equally & 0 & & & & \\
\hline \multirow{3}{*}{$\begin{array}{l}\text { Pulmonary } \\
\text { capacity }\end{array}$} & Negative grades & 0 & 0.00 & 0.00 & \multirow{3}{*}{$2.527 *$} & \multirow{3}{*}{0.012} \\
\hline & Positive grades & 8 & 4.50 & 36.00 & & \\
\hline & Equally & 0 & & & & \\
\hline \multirow{3}{*}{$\begin{array}{l}\text { Cooper } \quad \text { Test } \\
\text { Distance } \\
\text { "Running } 12 \mathrm{q} " \\
\end{array}$} & Negative grades & 0 & 0.00 & 0.00 & \multirow{3}{*}{$2.524 *$} & \multirow{3}{*}{0.012} \\
\hline & Positive grades & 8 & 4.50 & 36.00 & & \\
\hline & Equally & 0 & & & & \\
\hline \multirow{3}{*}{ VO2 MAX } & Negative grades & 0 & 0.00 & 0.00 & \multirow{3}{*}{$2.521 *$} & \multirow{3}{*}{0.012} \\
\hline & Positive grades & 8 & 4.50 & 36.00 & & \\
\hline & Equally & 0 & & & & \\
\hline \multirow{3}{*}{$\begin{array}{l}\text { The digital level } \\
\text { of running } 3000 \\
\mathrm{~m}\end{array}$} & Negative grades & 0 & 0.00 & 0.00 & \multirow{3}{*}{$2.521 *$} & \multirow{3}{*}{0.012} \\
\hline & Positive grades & 8 & 4.50 & 36.00 & & \\
\hline & Equally & 0 & & & & \\
\hline
\end{tabular}

\section{* الدالة 0.05}

Table (11) shows statistically significant differences between the tribal and remote records of the experimental group in the variables in

Assiut Journal For Sport Science Arts 
question and in favor of remote measurement.

Shape Number (8)
The level of significance of the differences between the tribal and remote records of the experimental group

Table (12)

Rate of improvement between the tribal and remote records of the experimental group in the variables under consideration $N=8$

\begin{tabular}{|c|c|c|c|c|}
\hline Variables & $\begin{array}{c}\text { unit } \\
\text { scaling }\end{array}$ & $\begin{array}{c}\text { Average } \\
\text { tribal } \\
\text { measurement }\end{array}$ & $\begin{array}{c}\text { Average } \\
\text { distance } \\
\text { measurement }\end{array}$ & $\begin{array}{c}\text { Rate of } \\
\text { improvement } \\
\%\end{array}$ \\
\hline $\begin{array}{l}\text { The broad jump of } \\
\text { stability }\end{array}$ & poison & 220.625 & 252.500 & 14.448 \\
\hline $\begin{array}{l}\text { The oblique ness of } \\
\text { standing }\end{array}$ & number & 30.000 & 35.750 & 19.167 \\
\hline Pulmonary capacity & degree & 4.948 & 5.449 & 10.131 \\
\hline $\begin{array}{lr}\text { Cooper } & \text { Test } \\
\text { Distance } & \text { "Running } \\
12 \mathrm{q} " & \\
\end{array}$ & meter & 2082.625 & 2296.000 & 10.245 \\
\hline VO2 MAX & Milliliter $/ \mathrm{kg} / \mathrm{s}$ & 35.273 & 40.043 & 13.523 \\
\hline $\begin{array}{l}\text { The digital level of } \\
\text { running } 3000 \mathrm{~m}\end{array}$ & second & 502.659 & 456.049 & 9.273 \\
\hline $\begin{array}{l}\text { The rate } \\
\text { between the tribal an } \\
\text { of the experimenta } \\
\text { variables under cons }\end{array}$ & $\begin{array}{l}\text { improve } \\
\mathrm{d} \text { remote rec } \\
\text { group in } \\
\text { ideration an }\end{array}$ & $\begin{array}{l}\text { favour } \\
\text { shown } \\
\text { improv } \\
(9.273 c\end{array}$ & $\begin{array}{l}\text { of remote } \\
\text { in table } \\
\text { ment rate } \\
-19.167 \%)\end{array}$ & $\begin{array}{l}\text { easurement is } \\
\text { 2, with the } \\
\text { anging from }\end{array}$ \\
\hline
\end{tabular}

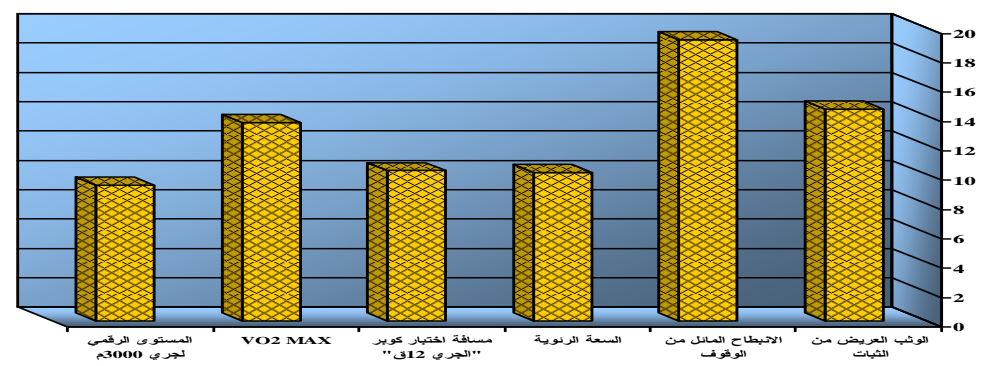

Shape Number (9)

Rate of improvement between the tribal and remote records of the experimental group

Discuss the results of the second imposition:

Imad Faraj Badrawi (2010)

(16) andYasser Abidin Suleiman
(2016) (24) agree that hipoxik training has a positive impact on physical and physiological qualities if used in a codified manner within the training program.

This is also indicated by Dufour(2005) (28) and Shmitt (2014) (33) that heboxic training has a

Assiut Journal For Sport Science Arts 
clear effect on the developmentof physical and physiologicaltraits when used in a scientific way codified by various training programs.

This is consistent with the findings of the researchers and the previous presentation in my schedule $(11,12)$ which indicates statistically significant differences between the tribal and remote records of theexperimental group in the variables in question and in favor of remote measurement as a result of the application of the program to them using the highland training mask during theprogram, which indicates a positive effect of exercise on the physical elements under research using hipbox training as we note and JoeD changed in the resultof the wide jump test of stability by an improvement of 14.4. $44 \%$ improved by $19.16 \%$ in the oblique dent test, $10.13 \%$ improvement in pulmonary amplitude measurement, $10.24 \%$ improvement in Cooper's test,

\section{Table (13)}

Indication of the differences between the two dimensions of the controlling and experimental groups In the variables under consideration $\mathrm{N} 1=\mathrm{N} 2=8$

\begin{tabular}{|c|c|c|c|c|c|}
\hline Variables & Groups & $\begin{array}{l}\text { Average } \\
\text { grades }\end{array}$ & $\begin{array}{l}\text { Total } \\
\text { ranks }\end{array}$ & $\begin{array}{c}\text { Mann-Whitney } \\
\text { U }\end{array}$ & Indication \\
\hline \multirow{2}{*}{$\begin{array}{l}\text { The broad jump of } \\
\text { stability }\end{array}$} & Experimental & 11.56 & 92.50 & \multirow{2}{*}{$7.500^{*}$} & \multirow{2}{*}{0.010} \\
\hline & The officer. & 5.44 & 43.50 & & \\
\hline \multirow{2}{*}{$\begin{array}{l}\text { The oblique ness of } \\
\text { standing }\end{array}$} & Experimental & 11.19 & 89.50 & \multirow{2}{*}{$10.500^{*}$} & \multirow{2}{*}{0.023} \\
\hline & The officer. & 5.81 & 46.50 & & \\
\hline \multirow{2}{*}{ Pulmonary capacity } & Experimental & 12.50 & 100.00 & \multirow{2}{*}{$0.000^{*}$} & \multirow{2}{*}{0.001} \\
\hline & The officer. & 4.50 & 36.00 & & \\
\hline \multirow{2}{*}{$\begin{array}{l}\text { Cooper Test Distance } \\
\text { "Running 12q" }\end{array}$} & Experimental & 12.50 & 100.00 & \multirow{2}{*}{$0.000^{*}$} & \multirow{2}{*}{0.001} \\
\hline & The officer. & 4.50 & 36.00 & & \\
\hline \multirow{2}{*}{ VO2 MAX } & Experimental & 12.50 & 100.00 & \multirow{2}{*}{$0.000 *$} & \multirow{2}{*}{0.001} \\
\hline & The officer. & 4.50 & 36.00 & & \\
\hline \multirow{2}{*}{$\begin{array}{l}\text { The digital level of } \\
\text { running } 3000 \mathrm{~m}\end{array}$} & Experimental & 5.38 & 43.00 & \multirow{2}{*}{$7.000^{*}$} & \multirow{2}{*}{0.009} \\
\hline & The officer. & 11.63 & 93.00 & & \\
\hline
\end{tabular}

* لالالالة 0.05

Assiut Journal For Sport Science Arts
$13.52 \%$ improvement inVO2MAX testing, $3,000 \mathrm{~m} / \mathrm{run}$ digital level of $9.27 \%$.

Thus, the second imposition, which states:

"There are statistically significant differences between the tribal and remote measurements of the experimental group in (capacity for men - muscular endurance - vital capacity - maximum consumption of oxygenyen - digital level of running $3000 \mathrm{~m}) "$

View and discuss the results of the third imposition:

View the results of the third imposition:

It states: "There are statistically significant differences between the two dimension measurements of the "controlled, experimental" groups in (capacity for men- muscular endurance- vital capacity- maximum oxygen consumption- digital running level of $3000 \mathrm{~m}) . "$ 
Table (13) shows statistically significant differences between the controlled and experimental groups in the variables in question and in favor of the experimental group.

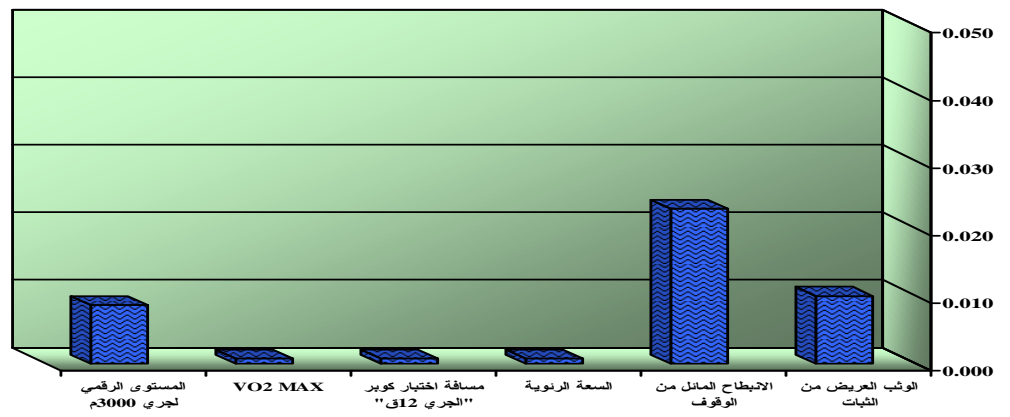

Shape Number (10)

The level of significance of the differences between the two dimensions of the control and experimental groups

Discuss the results of the third imposition:

Daniel Pierce (2013) (27) andMohamed Zakaria Jazira(2005) (21) agreed that heboxic exercises, which are carried out using a highland training mask, always have more positive results than those practiced without the use of the mask.

\section{Nasser Mustafa}

AlSuwaifi,Mohsen Ibrahim Ahmed (2010) (22) also agreed that exercise using a highland training mask(heboxic)excels in its results from exercise without using the highland training mask by up to twice the impact.

This is consistent with the findings of the two researchers of the neta and theprevious presentation in the table (13) and the previous results presented in my schedule $(11,12)$ which indicate statistically significant differences between the two distant recordsof the control group and the dimension of the experimental group in the variables under Research and in favor of the remote measurement of the experimental group as a result of the application of the landnamg to them using the highland training mask during the program, which indicates a positive effect of exercise practice on the physical elements in question using hipbox training for them in training without the use of the highland training mask, which is as shown in Table 13.

\section{Thethird imposition, which states:}

"There are statistically significant differences between the two dimension measurements of the "controlled, experimental" groups in (capacity for men - muscular endurance - biosurgy - maximum oxygen consumption - digital running level of $3000 \mathrm{~m}$ )"

Interpretation of results:

It is clear from the previous results presented in my schedule $(9,10)$ that there are statistically significant differences between the tribal and remote records of the control group in the variables in question and in favor of remote measurement, as a result of 
the application of the program to them, although they did not use the highland training mask during the program, which indicates a positive effect of exercise exercise on the elements in question as we note a change in the rate of improvement by up to $9.21 \%$ in the test of wide jump of stability $\mathrm{He}$ improved by $10.59 \%$ in the oblique scab test and improved by $5.08 \%$ in pulmonary capacity measurement anda $4.99 \%$ improvement in cooper's test, and we note an improvement of $6.58 \%$ in the VO2MAX test, as well as progress in the digital level of the $3000 \mathrm{~m} / \mathrm{m} / \mathrm{run}$ race, which has reached $5.99 \%$.

This is agreed byAbu Ala Ahmed Abdel Fattah (2003) (1) and Shining Ismail Nasser (2005) (11) that codified training programs always have a positive impact on trainees.

Rafi Saleh, Abdul Razeq alMajdi (2013) (6) also agrees that the differences between tribal and remote measurements in the control group as a result of the application of the exercises used in the training program in the traditional way have a positive result on the improved condition of athletes in the control group.

This is what Osama Ahmed Hassan, Shorouk Mahdi Kazem (2004) (5) points out that training programs have always had a positive impact on the development of athletes' physical and physiological abilities.

The researchers attributed this finding to a positive impact on the physical and physiological traits under consideration for the training program applied to the control group.
According to the researchers, the reason for the statistically significant differences is due to the effectiveness of the training program, whichis based on the improvement of the qualities under consideration as a result of the use ofthe exercises included in the training program, and this is consistent with Munib Abdullah Fathi (2007) (16).

The previous results presented in my schedule $(11,12)$ show statistically significant differences between the tribal and remote records of the experimental group in the variables in question and in favor of remote measurement, as a result of the application of the program to them using the highland training mask during the program, indicating a positive effect of exercise on the physical elements in question using hebuxik training, as we note a change in thetone ofthe broad jump test of stability by an improvement of $14.44 \%$ and improvement With $19.16 \%$ in the stand-down test, a $10.13 \%$ improvement in pulmonary capacity measurement, a $10.24 \%$ improvement in cooper's test, an improvement of $13.52 \%$ in the VO2MAX test, as well as progress inthe $3,000 \mathrm{~m} / \mathrm{m}$ digital standard, has reached $9.27 \%$.

This was agreed by Imad Faraj Badrawi (2010), (16) andYasser Abedin Suleiman (2016) (24), Dufour(200). (28) and "Shmitt"(2014) (33) in that heboxic training has a positive impact on physical and physiological qualitiesif used in acodified manner within the training program. 
The researchers attributed this finding to the fact that the application of the proposed program led to statistically significant differences between the tribal and remote records of the experimental group in the variables in question and in favor of remote measurement as a result of the application of the program to them using the highland training mask during the program, indicating a positive effect of exercise on the physical elements under consideration using hipboxtraining.

As evidenced by the previous results presented in table (13) and extracted from those previous results in my schedule $(11,12)$, which indicate statistically significant differences between the two dimensions of the control group and the remoteness of the experimental group in the variables under Research and in favor of the remote measurement of the experimental group as a result of the application of the program to them using the highland training mask during the program, which indicates a positive effect of exercise on the physical elements in question using hipbox training training for them in training without the use of the highland training mask, which is as shown in table 13.

Daniel Pierce (2013) andMohamed ZakariaJazira(2005) (21) agreed that heboxic exercises, which are used in a highland training mask, always have more positive results than those practiced without the use of the mask.

$$
\text { Nasser Mustafa Al- }
$$

(2010m) (22) also agreed that exercises using a highland training mask always outperform their results from training without using the mask by up to twice the impact.

The researchers attributed this result to a statistically significant positive effect on the physical and physiological qualities under consideration of the training program applied to the experimental group as a result of the use of the highland training mask, which is greater than the impact on the control group as a result of the application of the training program in the traditional way, as explained by Table 13 .

\section{Conclusions and recommendations:}

In the light of the research objectives, duties, approach used, within the research sample and the reference framework of studies and researches, and through statistical analysis, the following conclusions have been reached:

\section{First-Conclusions:}

1- There are statistically significant differences between the tribal and remote measurements of the control group in (man's ability - muscular endurance - biosurgy - maximum oxygen consumption - digital running level of $3000 \mathrm{~m}$ ).

2- $\quad$ There are statistically significant differences between the tribal and remote measurements of the experimental group in (man's ability muscular endurance - vital capacity maximum oxygen consumption - the digital level of running $3000 \mathrm{~m}$ ).

3- There are statistically significant differences between the two dimension measurements of the "controlling,

Assiut Journal For Sport Science Arts 
experimental" groups in (man's ability - muscular endurance - biosurgy maximum oxygen consumption digital running level of $3000 \mathrm{~m}$ ).

4- The proposed training program, which contains training using a highland mask, hasa positive impact on the development of (man-muscle endurance- biosurgy- maximum oxygen consumption- digital level ofrunning 3000) in favor of remotemeasurements.

5- Heboxic training is an effective alternative to highland training.

6- The method of training heboxic is often accompanied by an improvement in the general condition.

7- The results are positively consistent with other studies conducted in the Highlands.

\section{Recommendations:}

1- Implementation of the proposed program to train players of competitions (3000) meters/run.

2- Wear a highland mask while applying training programs for racing (3000) meters/running.

3- Wear a highland mask while working to increase the trainee's pulmonary capacity because of its positive impact on the development of periodic and respiratory performance.

4- Do more research on wearing a highland mask with different methods and training programs as well as with other sports for different age stages.

5- $\quad$ Training programs need to be prepared in the general and private preparation stages using the Highland Training Mask to develop different physical and physiological variables for athletes.

Assiut Journal For Sport Science Arts
6- Do more research on wearing a highland training mask and find outits effects on different physiologicalvariables.

7- Physical and physiological tests are needed as an indicator of the adaptation of functional equipment and evaluation of the training situation as a result of the use of the highland training mask as an alternative to highland training.

8- $\quad$ To educate players of various athletics competitions on the importance of using a high mask in parts of training periods and to inform them of its positive impact on improving vital and physiological functions and improving their digital level.

9- Take care of the rationing of periods of use of the highland mask during training.

10- Organizing training courses related to breathing control training for field and tracktrainers.

\section{References}

1. Abu Ala Ahmed Abdel Fattah (2003): Training and Sports Physiology, Arab Thought House, Cairo.

2. Bastussi Ahmed Bastussi(2014): Foundations for the development of muscle strength in the field of events and sports, Book Publishing Center, Cairo.

3. Bahaa al-Din Ibrahim Salameh (2000): The physiology of sports and the physical performance of blood clots, Arab Thought House I1.

4. Khaled Haddadi (2014): A comparative study of the results of highland and coastal city dwellers in the long half-distance "Long Study of 
the Last Ten Championships" (p. 52 October Journal of Sports and Technical Physical Activity Science and Practices (No. 06 SPAPSA Laboratory for Science and Practice of Sports and Rhythmic Physical Activities)

5- Djnosh Obstacle (2018): The reality of athletics training in the Highlands among athletics coaches Field study of the trainers of the semilong teams in The City of Khanshala. Ph.D. Letter. Faculty of Physical Education and Sports Sciences. El Haj Lakhdar Batna University. Algeria.

6. Rafi Saleh Fathi, Abdul Razzaq al-Majdi (2013): The impact of the use of highland masks on some aspects of neurological processes in the runnersof the arena and thefield, scientific journal Al-Araaqiya sports science, Volume 2, Issue 3, Baghdad, Iraq.

7. Rafi Saleh Fathi et al. (2009): Applications in sports physiology and training in the Highlands, I1, Tigris Publishing and Distribution House, Amman, Hashemite Kingdom of Jordan.

8. Resan Khreib, Abu Ala Abdel Fattah (2016): RiyadhJTraining, Book Publishing Center, Cairo.

9- Resan Khreib Majid: (2018): Applications in physiology and sports training, Al Shorouk Publishing House, Jordan.

10-Saad eddin Chernoubi, Abdel Moneim Ibrahim (2001): Field and track competitions, Art Radiation House, Alexandria,Egypt.

11. Shining AsmaAyal Nasser (2005): Long-distance highland training physiology, Iraqi Electronic Scientific Academy, Iraq.

12. Safaa Abdul Wahab Ismail, Maher Abdul Latif Aref (2014): The impact of highland and cliff exercises on the balance of power is indicative of the electrical activity of the muscles of the two men working and contrary to the footballers, magazine of the Faculty of Education for Mathematics for Girls University of Baghdad, Volume 13, Issue 4, Baghdad, Iraq.

13. Amer Ibrahim (2013): Scientific research and use of information sources, Cultural Affairs House, Baghdad, Iraq.

14. Abdel Rahman Abdel Hamid Zaher (2006): Massage Physiology and Sports Hospital, Book Publishing Center, Cairo.

15. Abdel Moneim Badir, Youssef Dahab, Mohammed Sharaf (2012): Sports Biology, Freedom Library, Cairo I2.

16. Emad Faraj Al Badrawi (2016): A special endurance training program and its impact on some biochemical and physiological variables and the physical effort of the players $(5000 \mathrm{~m})$ an unpublished $\mathrm{PhD}$ letter from the Faculty of Sports Education for Girls in Fleming,University of Alexandria, Egypt.

17. Aladdin Mohamed Aliwa (2000): Sports Health and Recovery and Nutrition Activity for Athletes, First Edition, Dar al-Wafa,Alexandria, Egypt.

18. Mohamed Ibrahim Shehata (2005): Breathing in Motor Activity, Egyptian Library of Printing and Publishing, Alexandria,Egypt. 
19. Mufti Ibrahim Hammad (2001): Modern sports training planning, application and leadership, Arab Thought House, Cairo.

20. Mohamed Abdel Ghani Osman (2008): Kinetics and SportsTraining, Arab Thought House, Cairo, Egypt.

21. Mohamed Zakaria Islands Hamed (2005): The impact of heboxic training on the efficiency of the respiratory system and the level of performance of young boxing, published master's study, Faculty of Sports Education, Zagazig University, Egypt.

22. Nasser Mustafa AlSuwaifi,Mohsen Ibrahim Ahmed (2010): Hadith in Sports Physiology, Safa Printing House, Minya, Egypt.

23- H.R. Edersen (2010): Origins of Education,I2, Translated by Abdul Ali Nasif,Faculty of Physical Education and SportsSciences.University of Baghdad, Baghdad, Iraq.

24. Yasser Abidin Suleiman (2016): Theeffectiveness of hippyxi training in developing some special functional abilities and the level of digital achievement of the contestants (1500) meters, published research, scientific journal of physical education and sports sciences, Faculty of Sports Education Benin Al-Herm, Helwan University.

25- Aroussen, L. (2006). Training at altitude and effect on sea level performance.
26- Bertin, O., and Michau, R. (2011). Altitude training, AEFA, 204p.

27- Daniel Pierce (2013) Repeated pre-season hypoxic sprinttraning may improve rugby performance . London south bormk university. british journal of sport medicine.

28-Dufour, (2005), Altitude training / Published $\mathrm{PhD}$ thesis.

29-Porcari JP, Probst: L, Forrester K, Doberstein S,Foster C, CressML, Schmidt K)2016) : Effect of Wearing the Elevation Training Mask on Aerobic Capacity, Lung Function, and Hematological Variables, J Sports Sci ed.vol.,15,

30-Larry Kenny ,Jack :Wilmore, David Costill2011: physiology of sport and exercise with web study guide , 5th edition ,Human kinetic ,USA,.

31- Mackenzie, B. (2005) 101 Performance evaluation tests. London: Electric World plc.

32- Robach , P.(2016) Methods live up and train at the bottom such as endurance performance, medical department, national ski school.

33-Shmitt,(2014) Altitude training / Published $\mathrm{PhD}$ thesis.

International Information Network:

34- https://forum.kooora.com/f.aspx?t=2732998

35- Https://ar.wikipedia.org/wiki/\%D8\% A5\%D8\%B9\%D9\%84\%D8\%A

7\%D9\%86_\%D9\%87\%D9\%84\%D8\%B3

$\%$ D9\%86\%D9\%83\%D9\%8A 